\title{
Mycotoxin producing ability of Aspergillus tamarii
}

\author{
Tetsuhisa Goto*1, Yoko ITO*2, Stephen W. Peterson*3 \\ and Donald T. WICKLOW*3
}

(Received Sept. 30, 1996 ; Accepted Dec. 17, 1996)

\begin{abstract}
後藤 哲久*1，伊藤 陽子*2，ステフェン・W・ピーターソン*3，ドナルド・T・
ウィックロー*3 : アスペルギルス・タマリのマイコトキシン産生能
\end{abstract}

\begin{abstract}
Summary
Aspergillus tamarii is known to produce mycotoxins such as cyclopiazonic acid (CPA) and kojic acid (KA). Recently we isolated several cultures of $A$. tamarii from Japanese tea fields and found one of the isolates "No. 19", and single-spore cultures (NRRL 25517, 25518, 25519) derived from this isolate, produced substantial quantities of aflatoxin $B_{1}$ and $B_{2}$. Here we report the results of a limited survey of $15 \mathrm{~A}$. tamarii strains isolated from Japanese tea fields, one strain from silk worm excrement and 29 strains received from culture collections. Most A. tamarii isolates produced CPA and KA but only the strains derived from isolate "No. 19" and strain NRRL 443 produced aflatoxins $\mathrm{B}_{1}$ and $\mathrm{B}_{2}$. Each aflatoxin-producing strain of $A$. tamarii showed yellow-green colors in young colonies and did not darken in age, suggestive of the "bronze series". The relation between the levels of CPA or KA production by the individual strains was very weak.
\end{abstract}

Key words : Aspergillus tamarii, アスペルギルス・タマリ；Aflatoxin, アフラトキシン； Cyclopiazonic acid, サイクロピアゾン酸；Kojic acid, こうじ酸

Aspergillus tamarii Kita, a species classified in the A. flavus group (subgenus Circumdati section Flavi $^{1)}$, is often isolated from soil and agricultural commodities ${ }^{2}$. This fungus reportedly produces mycotoxins such as cyclopiazonic acid (CPA) and kojic acid (KA), but not aflatoxins ${ }^{3,4}$. Among $A$. flavus group, $A$. flavus, $A$. parasiticus and $A$. nomius produce aflatoxins, A. flavus, $A$. oryzae and $A$. tamarii produce CPA and most of the $A$. flavus group including $A$. sojae produce $\mathrm{KA}^{3,4)}$.

We recently isolated several aflatoxigenic $A$. flavus group strains from Japanese tea field soils and found one of the isolates produced substantial quantities of aflatoxins $\mathrm{B}_{1}\left(\mathrm{AFB}_{1}\right)$ and $\mathrm{B}_{2}$ $\left(\mathrm{AFB}_{2}\right)^{5,6)}$. Examination of cultures representing single-spore isolates of subcultures of isolate No. 195,6) (NRRL 25517, NRRL 25518, NRRL 25519) suggested taxonomic placement in the "bronze series" of Thom and Raper $(1945)^{7}$. This prompted us to examine other A. tamarii

${ }^{* 1}$ National Food Research Institute, Ministry of Agriculture, Forestry and Fisheries (Tsukuba 305, Japan) 農林水産省食品総合研究所（テ305 茨城県つくば市観音台 2-1-2）

*2 National Research Institute for Vegetables, Ornamental Plants and Tea, Ministry of Agriculture, Forestry and Fisheries (Kanaya, Shizuoka 428, Japan)

農林水産省野菜・茶業試験場（广428 静岡県榛原郡金谷町金谷 2769）

${ }^{* 3}$ National Center for Agricultural Utilization Research, ARS/USDA (Peoria, IL 61604, USA)

農務省農業利用研究所（61604 米国イリノイ州ペオリア市） 
strains for their aflatoxins, CPA and KA productivity.

\section{Materials and Methods}

Fungal strains The 45 cultures of $A$. tamarii that were examined in this study included 11 isolates (15 strains) from Japanese tea field soils, one isolate from silk worm excrement, and cultures obtained from culture collections including: ARS Culture Collection (National Center for Agricultural Utilization Research, USA) (22 strains); IAM Culture Collection (Univ. of Tokyo) (5 strains) ; NFRI Culture Collection (Ministry of Agriculture, Forestry and Fisheries, Japan) (2 strains).

Analysis of aflatoxin Fungi were inoculated in $10 \mathrm{ml}$ of glucose-yeast extract liquid medium in $18 \times 180 \mathrm{~mm}$ test tube and incubated for 1 week at $25^{\circ} \mathrm{C}$ in the dark. Five grams of culture medium was placed in a $18 \times 180 \mathrm{~mm}$ test tube and mixed with $300 \mathrm{mg}$ of $\mathrm{KCl}$ and five $\mathrm{ml}$ of methanol. Aflatoxins were extracted twice with three $\mathrm{ml}$ of chloroform. The chloroform extracts were combined and evaporated to dryness under $\mathrm{N}_{2}$ gas stream. The residue was dissolved in benzene-acetonitrile $(98+2, \mathrm{v} / \mathrm{v})$ then analyzed by $\mathrm{TLC}^{6,8}$.

Analysis of cyclopiazonic acid Fungi were inoculated in $10 \mathrm{ml}$ of modified Czapek-Dox liquid medium in $18 \times 180 \mathrm{ml}$ test tube and incubated for 10 days at $30^{\circ} \mathrm{C}$ in the dark. One $\mathrm{ml}$ of culture medium was absorbed to one gram of equal weight mixture of Celite 545 and anhyd. $\mathrm{Na}_{2} \mathrm{SO}_{4}$ in $13 \times 100 \mathrm{~mm}$ test tube. Cyclopiazonic acid was extracted in one $\mathrm{ml}$ of ethylacetate and analyzed by HPLC ${ }^{9,10)}$.

Analysis of kojic acid Fungi were inoculated in $10 \mathrm{ml}$ of glucose-peptone medium ${ }^{11}$ in $18 \times 130$ $\mathrm{mm}$ test tube and incubated for 2 weeks at $30^{\circ} \mathrm{C}$ in the dark. The culture medium was directly injected, in some case diluted with mobile phase, into HPLC column. Kojic acid was detected at the absorbance of $270 \mathrm{~nm}^{12)}$.

\section{Results and Discussion}

As shown in Table 1, most $A$. tamarii strains produced KA and CPA. Three strains did not produce detectable amounts of KA and seven strains did not produce detectable amounts of CPA. Four strains produced aflatoxins, including NRRL 443 sent to Charles Thom in 1923 by Da Fonseca, Brazil as Aspergillus spadix Amons (Thom No. 277-4707.757) and three strains derived from subcultures of isolate No. $19^{5)}$ from tea field soil in Japan.

The quantities of mycotoxins produced varied among strains. The highest KA producer made nearly $3.5 \%(\mathrm{w} / \mathrm{v})$ of KA in the liquid medium. For CPA some strains produced more than $13 \mathrm{ppm}$. Two out of three non KA producers did not produce detectable amounts of CPA while a third non KA producer formed relatively small quantities of CPA. Strong CPA producers tended to produce more $\mathrm{KA}$, however the association between the production of these two mycotoxins was weak (Fig. 1).

Aflatoxigenic strains produced $\mathrm{AFB}_{1}$ and $\mathrm{AFB}_{2}$ but did not produce detectable amounts of AFGs. These strains made more than one $(>1)$ ppm of CPA and quantities of KA (1.9\%). Colonies of these aflatoxigenic strains initially showed some yellow-green colors becoming bronze colored in age. The colonies did not continue to darken becoming dark brown as 
Table 1 Mycotoxin productivity of $A$. tamarii.

\begin{tabular}{|c|c|c|c|c|c|}
\hline Strain & & CPA (ppm) & $\mathrm{AFB}_{1}(\mathrm{ppm})$ & $\mathrm{AFB}_{2}(\mathrm{ppm})$ & KA (\%) \\
\hline $87 \mathrm{~K} 5723$ & (NRRL 25586) & 0.19 & N.D. & N.D. & 0.84 \\
\hline $93 \mathrm{MZ2A}$ & $(\mathrm{NRRL} 25400)^{* 1}$ & 7.8 & N.D. & N.D. & 0.95 \\
\hline $93 \mathrm{MZ2C}$ & $(\mathrm{NRRL} 25401)^{* 1}$ & 3.9 & N.D. & N.D. & 2.70 \\
\hline 93MZ2D & $(\mathrm{NRRL} 25517)^{* 1}$ & 1.7 & 30 & 0.1 & 1.92 \\
\hline $93 \mathrm{MZ2E}$ & $(\mathrm{NRRL} 25518)^{* 1}$ & 2.5 & 30 & 0.2 & 2.38 \\
\hline $93 \mathrm{MZ2F}$ & $($ NRRL 25519)*1 & 1.8 & 30 & 0.2 & 2.01 \\
\hline $93 \mathrm{KO} 6$ & (NRRL 25399) & 0.17 & N.D. & N.D. & 2.43 \\
\hline $94 \mathrm{SZ1}-1$ & (NRRL 25402) & 1.7 & N.D. & N.D. & 2.28 \\
\hline $94 \mathrm{KO} 1$ & (NRRL 25403) & 0.22 & N.D. & N.D. & 1.04 \\
\hline $94 \mathrm{KO} 2$ & (NRRL 25404) & N.D. ${ }^{* 2}$ & N.D. & N.D. & 0.13 \\
\hline $95 \mathrm{KO} 1$ & (NRRL 25565) & 0.69 & N.D. & N.D. & 0.53 \\
\hline $95 \mathrm{KO} 7$ & (NRRL 25570) & 0.36 & N.D. & N.D. & 0.05 \\
\hline $96 \mathrm{MZ1}$ & (NRRL 25578) & 5.0 & N.D. ${ }^{* 3}$ & N.D. ${ }^{* 3}$ & 0.89 \\
\hline $96 \mathrm{MZ2}$ & (NRRL 25579) & 13.0 & N.D. & N.D. & 1.21 \\
\hline $96 \mathrm{MZ3}$ & (NRRL 25580) & 2.5 & N.D. & N.D. & 0.46 \\
\hline 96MZ5 & (NRRL 25626) & 2.4 & N.D. & N.D. & 0.87 \\
\hline IAM 2138 & & N.D. & N.D. & N.D. & 1.56 \\
\hline IAM 2499 & & 3.0 & N.D. & N.D. & 1.56 \\
\hline IAM 2502 & & N.D. & N.D. & N.D. & 1.64 \\
\hline IAM 13907 & & 13.9 & N.D. & N.D. & 3.12 \\
\hline IAM 13908 & & 6.4 & N.D. & N.D. & 2.63 \\
\hline NFRI 1172 & & N.D. & N.D. & N.D. & 1.43 \\
\hline NFRI 1296 & & 6.4 & N.D. & N.D. & 1.79 \\
\hline NRRL 427 & & 3.5 & N.D. & N.D. & 0.22 \\
\hline NRRL 428 & & 1.8 & N.D. & N.D. & 2.23 \\
\hline NRRL 429 & & 0.8 & N.D. & N.D. & 0.99 \\
\hline NRRL 430 & & 3.6 & N.D. & N.D. & 3.28 \\
\hline NRRL 431 & & 0.9 & N.D. & N.D. & 2.65 \\
\hline NRRL 432 & & 1.1 & N.D. & N.D. & 2.43 \\
\hline NRRL 433 & & 1.5 & N.D. & N.D. & 0.05 \\
\hline NRRL 434 & & 0.41 & N.D. & N.D. & N.D. ${ }^{* 4}$ \\
\hline NRRL 435 & & 2.7 & N.D. & N.D. & 1.77 \\
\hline NRRL 436 & & 6.6 & N.D. & N.D. & 3.05 \\
\hline NRRL 437 & & 0.5 & N.D. & N.D. & 0.42 \\
\hline NRRL 438 & & 3.0 & N.D. & N.D. & 0.49 \\
\hline NRRL 439 & & 6.8 & N.D. & N.D. & 0.18 \\
\hline NRRL 440 & & N.D. & N.D. & N.D. & N.D. \\
\hline NRRL 441 & & 0.4 & N.D. & N.D. & 0.27 \\
\hline NRRL 443 & & 3.1 & 3.8 & 0.04 & 3.46 \\
\hline NRRL 559 & & 0.1 & N.D. & N.D. & 0.41 \\
\hline NRRL 572 & & N.D. & N.D. & N.D. & 0.04 \\
\hline NRRL 1252 & & 5.1 & N.D. & N.D. & 1.18 \\
\hline NRRL 1654 & & 0.5 & N.D. & N.D. & 1.13 \\
\hline NRRL 4960 & & N.D. & N.D. & N.D. & N.D. \\
\hline NRRL 13139 & & 11.4 & N.D. & N.D. & 1.57 \\
\hline
\end{tabular}

${ }^{* 1}$ : derived from isolate "No. 19" (Ref. 5).

*2: Not Detected, Detection limit for cyclopiazonic acid was $0.01 \mathrm{ppm}$.

*3 : Detection limits for aflatoxins were $0.5 \mathrm{ppb}$.

${ }^{* 4}$ : Detection limit for kojic acid was $0.01 \%$. 


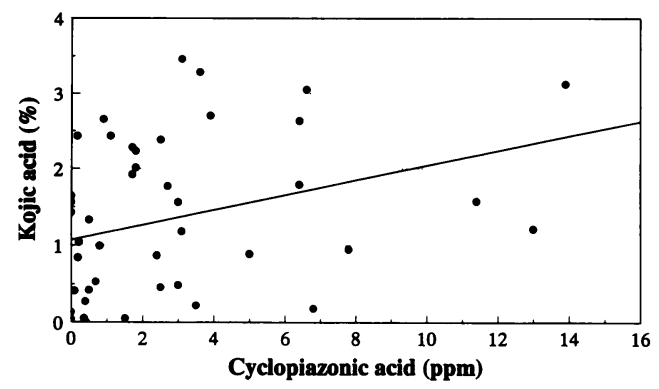

Fig. 1 Relation the level of cyclopiazonic acid and kojic acid production.

described for A. tamarii $i^{1)}$ and therefore are suggestive of strains included in the "bronze series" of $A$. tamarii $^{7}$.

\section{References}

1) Raper, K. B., Fennel, D. I.: “The Genus Aspergillus”, (1965), Williams \& Wilkins, Baltimore.

2) Manabe, M., Tsuruta, O., Goto, T., Matsuura, S. : Rept. Natl. Food Res. Inst., No. 33, 49 (1978).

3) Samson, R. A., Hoekstra, E. S., Frisvad, J. C., Filtenborg, O.: "Introduction to Food-borne Fungi", p. 52 (1995), Centraalbureau voor Schimmelcultures, Baarn.

4) Wilson, B. J.: "Microbial Toxins VI”, (eds. Ciegler, A., Kadis, S., Ajl, S. I.), p. 207 (1971), Academic Press, N.Y.

5) Ito, Y., Goto, T.: Mycotoxins, 40, 52 (1994).

6) Goto, T., Wicklow, D. T., Ito, Y.: Appl. Environ. Microbiol., 62, 4036 (1996).

7) Thom, C., Raper, K. B.: "A Manual of the Aspergilli", (1945), Williams \& Wilkins, Baltimore.

8) Wongurai, A., Goto, T., Manabe, M.: Rept. Natl. Food Res. Inst., No. 54, 53 (1990).

9) Goto, T., Shinnshi, E., Tanaka, K., Manabe, M.: Rept. Natl. Food Res. Inst., No. 51, 23 (1987).

10) Goto, T., Shinnshi, E., Tanaka, K., Manabe, M. : Agric. Biol. Chem., 51, 2581 (1987).

11) Sakaguchi, K. : Nippon Nogei Kagaku Kaishi, 8, 205 (1933) (in Japanese).

12) Manabe, M., Tanaka, K., Goto, T., Matsuura, S.: “Toxigenic Fungi”, p. 4 (1984), Elsevier, Amsterdam. 